\title{
Analysis of Students' Speaking Ability in Video Project at STKIP Muhammadiyah Muara Bungo
}

\author{
Diah Savitri ${ }^{1, *}$ Havid Ardi ${ }^{1}$ \\ ${ }^{1}$ English Education of Graduate Program, Universitas Negeri Padang, Padang, Indonesia \\ ${ }^{*}$ Corresponding author. Email: diahsavitrinando@gmail.com
}

\begin{abstract}
The current advancement of vlogs in YouTube channel has challenged lecturers to make use of its potential for students' speaking enhancement. This research was aimed to investigate students' speaking ability seen from their video projects. These video projects were vlogs made by the first semester students of English language education department academic year 2019/2020 of STKIP Muhammadiyah Muara Bungo as the assignment in Basic Spoken English class. Descriptive quantitative research was used in order to investigate the improvement of students' speaking ability. There were 27 vlogs that became the data for this research. They were from three different assignments from nine students who were categorized from three different level of English proficiency (high, average, and low). Scoring rubric for speaking proposed by Brown and Abeywickrama [1] was used. The result showed that the students spoke confidently. However, their speaking ability was varied; some students had an improvement whereas others did not. Mastering grammar and vocabulary became the most influencing factors in the improvement of the speaking ability based on the data gathered. It means that the use of vlog as the video project assignment is more effective if the students master in grammar as well as/and have enough vocabulary related to the topic discussed, so that their speaking ability improves.
\end{abstract}

Keywords: Speaking ability, video project, and vlog

\section{INTRODUCTION}

Speaking is one of the essential skills that must be mastered by English language education department students. It is considered to be a difficult skill for the students. The students will acquire English faster and better if they produce comprehensible input through speaking. If they have this skill, they can speak English fluently and engage in a meaningful interaction, so they will not get trouble in communication when they encounter real-life situations.

Lecturers use a variety of activities to get their students participate on speaking. Their choice of such activities will depend on who the students are, how passionate they are about speaking and what kind of speaking they need to practice. There are various activities that the lecturers can apply, and the activities depend on what purpose they want to attain. Some of them give the students chance to have role plays, debates, or group discussion with their friends. The others may ask them to have presentation or speech in front of the class as more challenging activities.

However, the students often face some obstacles related to speaking especially dealing with language components such as poor in grammar, lack of vocabulary, and incorrect pronunciation [2]. Moreover, Rakhmanina and Kusumaningrum also found out in their research that those elements also needed for students to master speaking skill [3]. Vocabulary is important to help students in delivering idea and information. Without vocabulary, students cannot express their idea in proper words. Grammar is important to help students deliver idea and information using good structure of English. Furthermore, good grammar helps students understand and perceive information. Pronunciation helps students to produce good sound and English voice. Besides, good pronunciation leads students to have a better interpretation. Incorrect pronunciation results misunderstanding.

Because of those difficulties, students tend to be passive in the class even though they are exposed with English since they were in the elementary school. Moreover, by having those difficulties can prevent students' improvement on speaking English. In fact, a lot of practices inside and outside the classroom are required in order to master English speaking skill.

Based on the preliminary research, it was found that the lecturer in STKIP Muhammadiyah Muara Bungo used YouTube channel as the medium for the students to share their vlogs. These vlogs were the project that the lecturer gave in Basic Spoken English subject. The lecturer wanted to see whether the speaking ability of the students improve or not. The students were asked to upload their videos on YouTube channel and they were asked to give comment to their friends' videos after watching them. The lecturer intended to encourage the students to speak. The students are struggling with speaking activities. They cannot have 
significant improvement due to the lack of basic ability like vocabulary mastery and basic structure mastery and the low motivation to have more practice outside of the classroom.

This media was chosen by the lecturer since they like to play gadget and more interested to do any activities with their gadget rather than practicing their English. Moreover, all of them have the gadget that can be used to record a video. The lecturer wants to use something that they have and like to do and turn it into fun learning activities which can help them to improve their speaking ability. Vlogging is a popular among them and they like to make vlog by using Indonesian language during their free time but not in English. Turning their behavior into learning will not be so difficult, especially because they have the motivation to do. This media is also beneficial for them because they can view and check their work in the future.

There were some research that had been done related to the use of video and vlog in learning English. [4], [5], and [6] did research on using video in improving students' speaking ability. The results showed that by using video the students' speaking ability improved.

On the other hand, the research that are dealing with the use of vlog are such as [7], [8], [9], and [10]. They investigated the students' motivation and confidence, students' perception and also how vlogging can improve students' speaking ability. The results of the research showed that the students' motivation and confidence improved, they had good perception on the use of vlog to enhance speaking skill, and vlog can help them in learning speaking and foster their speaking skill.

In addition, Maulidah found that vlog significantly improves students' speaking ability [11]. She mentioned that vlog can boost students' encouragement by providing fun learning process. In addition, it promotes good presentation in speaking performance. The students will be able to interact with authentic environment to get a lot of exposure in speaking. Moreover, the students get a chance to build up their autonomous learning. Those several things bring students to enhance their progress in speaking. In reference to the explanation above, this research intended to analyze the students' speaking ability seen from their vlogs; whether by implementing vlog assignment the students can overcome their speaking problems or not so that their speaking ability improve.

\section{METHOD}

This research employed descriptive quantitative research. The research was conducted at STKIP Muhammadiyah Muara Bungo. The source of data for this research was students' vlogs. These vlogs were the assignment made by the first semester students of academic year 2019/2020 who took Basic Spoken English subject. There were 27 vlogs that became the data for this research. These vlogs were taken from three different assignments. The first vlog was talking about favorite activity, the second vlog was about last holiday, and the last vlog was using comparative and superlative sentences in speaking. Each vlog was consisted of nine vlogs.
There were 19 students who took Basic Spoken English. 9 students were purposively selected as the sample by considering the level of their English proficiency; high, average, and low to avoid bias. This proficiency level was gotten from the pre-test that was conducted by the lecturer at the beginning of the class before implementing vlog assignment. There were three students for each level. Time series analysis was used to see the progression of students' speaking ability in sequence from vlog 1 until vlog 3 .

To analyze students' speaking ability, scoring rubric for speaking proposed by Brown and Abeywickrama [1] was used. This speaking rubric is consisted of five indicators. They are grammar, vocabulary, comprehension, fluency, and pronunciation. Inter-rater reliability was used in this research. It refers to the reliability of two or more independent scorers [12]. There were two raters in investigating students' speaking ability from vlog, namely English lecturer of Basic Spoken English subject and the researcher herself. The formula suggested by Sudijono [13] was used to find out the score of students' speaking ability.

\section{RESULT AND DISCUSSION}

The objective of Basic Spoken English class is to help students learn general English in terms of speaking skill of elementary level using basic grammar, language functions and vocabularies related to limited topics of everyday conversation. It also helps students to comprehend and converse daily English topic and areas of special interest. Therefore, the students are expected to improve their speaking ability by creating vlogs outside the class where the students can practice to use the tense all together confidently without afraid of making mistake in an assignment of "a vlog creation".

In order to see whether the vlog is effective in enhancing the students to speak English, this research analyzed the improvement of the students' speaking ability from the first vlog assignment until the third vlog assignment through the scores of the students' speaking ability. Scoring rubric for speaking proposed by Brown and Abeywickrama [1] was used. Grammar, vocabulary, comprehension, fluency, and pronunciation became the indicators in assessing the students' speaking ability. Interrater reliability was used. The final score of the students' speaking ability was from the assessment of the lecturer and the researcher. Based on the finding of the research, the data from the both raters could be simplified as in the following table. 
Table 1. The Final Scores of the Students' Speaking Ability

\begin{tabular}{|c|c|c|c|}
\hline \multirow{2}{*}{ Participants } & \multicolumn{3}{|c|}{ The Scores of Students' Speaking } \\
& Ability & Vlog 3 \\
\cline { 2 - 4 } & Vlog 1 & Vlog 2 & Vlog \\
\hline Student 1 & 0,8 & 0,8 & 0,8 \\
\hline Student 2 & 0,74 & 0,68 & 0,72 \\
\hline Student 3 & 0,72 & 0,78 & 0,36 \\
\hline Student 4 & 0,6 & 0,6 & 0,72 \\
\hline Student 5 & 0,64 & 0,64 & 0,72 \\
\hline Student 6 & 0,8 & 0,46 & 0,58 \\
\hline Student 7 & 0,56 & 0,68 & 0,8 \\
\hline Student 8 & 0,42 & 0,48 & 0,4 \\
\hline Student 9 & 0,52 & 0,48 & 0,48 \\
\hline
\end{tabular}

The table above shows the final score of the students' speaking ability from vlog $1, \operatorname{vog} 2$, and vlog 3 . Based on the data above, the table shows that there were nine participants in this research. As mentioned previously, these participants were divided into three levels of English proficiency. Student 1, 2, and 3 were included into a group of students who had high level of English proficiency. Student 4,5 , and 6 were included into the average level whereas student 7, 8, and 9 were in the low level of English proficiency. The table also shows that the scores of some students had increased whereas others had not. In order to see the progression of students' speaking ability easily, the data above could be drawn as in the following graphs.

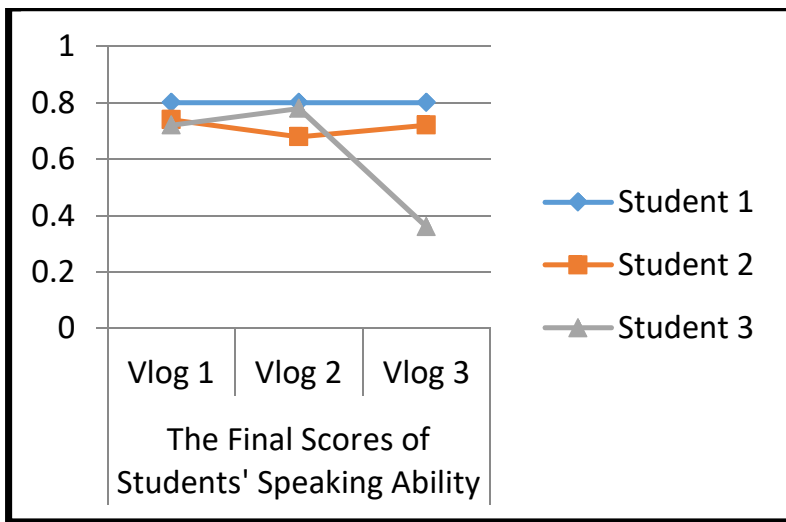

Graph 1. The Final Scores of the Students' Speaking Ability for High Level Students

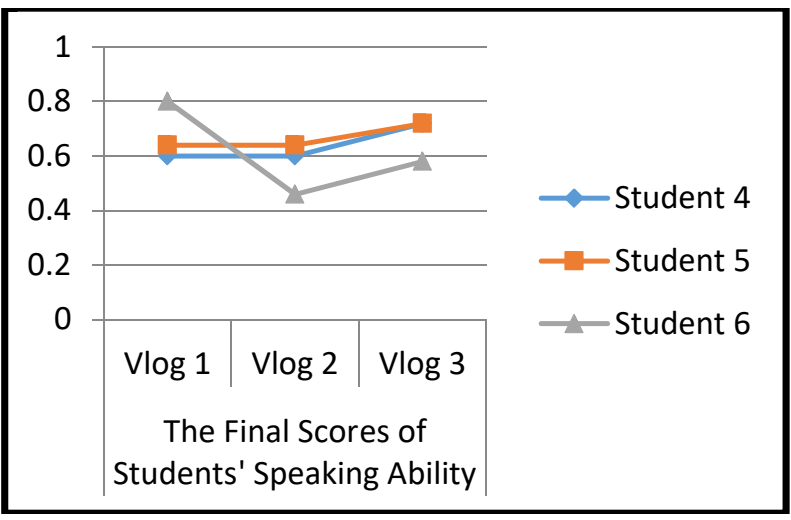

Graph 2. The Final Scores of the Students' Speaking Ability for Average Level Students



Graph 3. The Final Scores of the Students' Speaking Ability for Low Level Students

Graph 1 shows the scores of the students speaking ability for the high level students. From the graph, it can be seen that the speaking ability of the students are varied. The speaking ability of student 1 is the same from vlog 1 until vlog 3. There was no improvement. On the other hand, student 2 had a decreased score in vlog 2 . From the data, student 2 had difficulty in grammar and vocabulary related to topic in vlog 2 (last holiday). Student 3 had a significant decreasing score in vlog 3. Comparative and superlative that became the topic for vlog 3 were difficult for the student 3 to be mastered based on the data.

Graph 2 shows the scores of the students speaking ability for the average level students. The scores of the students in this group decreased in vlog 2 . From the data gathered, the use of past tense became the main problem for them during speaking. They like to use present tense while speaking about past tense. It means that mastering grammar is necessary for them so that their speaking improved.

Graph 3, on the other hand, shows that student 7 had a significant improvement from vlog 1 until vlog 3 . It was proved by the increasing of the students' speaking score. Meanwhile, student 8 had an improvement in vlog 2 but in vlog 3, the score of the student 8 decreased. On the contrary, the score of student 9 decreased in vlog 2 but had the same score with vlog 3 . 
From the finding above, the result shows that from those nine participants there was only one participant that showed the improvement in speaking ability from vlog 1 until vlog 3. The speaking ability increased significantly. Another participant, on the contrary, had stable capability in speaking based on the data provided. For the rest of the participants, they had an improvement in one topic and a decreased capability of speaking in another topic. The data showed that the causes of the problem were poor in grammar and lack of vocabulary. It is in line with the result of the research conducted by Azizah [14]. The research found out that most of the students were difficult to speak because of lack of vocabulary, lack of fluency and grammar, fear of making mistakes and nervousness.

Spoken language is easy to perform but in some cases, it is difficult [15]. Therefore, giving the students chances to practice what they have learned will help them to recall their knowledge and to keep engaged to English when they are beyond the class. Vlogging assignment is one of the alternative means that suitable with the students today who enjoy making vlogs in their everyday life. As digital natives, they like to perform and share everything online which make vlogging becomes one of the best alternatives for English speaking practice. This media should be employed intelligently so that the improvement of speaking ability achieved.

\section{CONCLUSION}

Based on the research findings and discussions, it can be concluded that in implementing vlog assignment the lecturer must consider some aspects to make the vlog really gives a great contribution to the students' speaking ability like factors that influence speaking for instance grammar, vocabulary, pronunciation, fluency, and comprehension, topics or themes that are suitable with students' interest and objective of the lesson, give clear time duration for vlogging assignment and time limitation for finishing vlogging assignment, discuss problems and solutions that may occur during speaking and vlogging process, and encourage the students to explore their capabilities.

\section{REFERENCES}

[1] H. D. Brown and P. Abeywickrama, Language Assessment: Principles and Classroom Practices, $2^{\text {nd }}$ Edition, New York: Pearson Education, 2010.

[2] J. C. Richards, Teaching Listening and Speaking From Theory to Practice, New York: Cambridge University Press, 2008.

[3] L. Rakhmanina and D. Kusumaningrum, "The Effectiveness of Video Blogging in Teaching Speaking Viewed From Students' Learning Motivation," Proceedings of the Fifth International Seminar on English Language and Teaching (ISELT 5). pp. 27-34, May 9-10, 2017.

[4] A. Mustikawati, "The Effectiveness of Using Video in Teaching Speaking for the Eighth Grade Students of SMP N 1 Manisrenggo,"ePrints@UNY, 1 September 2015.
[Online]. https://eprints.uny.ac.id/25728/ [Retrieved on October 3, 2019].

[5] R. Safitri, 'Improving the Students' English Speaking Skill in Class XA of State Senior High School 1 Gamping through Videos in the Academic Year of 2013/2014," ePrints@UNY, 22 May 2015. [Online]. https://eprints.uny.ac.id/19256/ [Retrieved on October 3, 2019].

[6] S. P. T. Sari, "The Use of Videos to Improve the Students' Speaking Skills at Class VII B of SMPN 2 Patuk in the Academic Year of 2014/2015,”ePrints@UNY, 30 July 2015. [Online]. https://eprints.uny.ac.id/23845/ [Retrieved on October 3, 2019].

[7] P. Sari, "Using Vlog in the Youtube Channel as a Means to Improve Students' Motivation and Confidence to Speak English in Intermediate 1 Level of LB-LIA Jambi," International Journal of English Language and Teaching, vol. 1 Issue 1, pp. 38-44, September 2017.

[8] N. S. Safitri and I. Khoiriyah, "Students' Perceptions on the Use of English Vlog (Video Blog) to Enhance Speaking Skill," The $5^{\text {th }}$ AASIC 2017, pp. 240-247, July 26-27, 2017.

[9] A. S. Rahayu and V. Nurviyani, "A Study of Students' Speaking Skill through Vlog," Jurnal JOEPALLT, vol. 6, no. 2, 2018.

[10] N. Lestari, "Improving the Speaking Skill by Vlog (Video Blog) as Learning Media: The EFL Students Perspective," International Journal of Academic Research in Business and Social Sciences, vol. 9, no. 1, pp. 915-925, January 2019.

[11] I. Maulidah, "Vlog: The Mean to Improve Students' Speaking Ability," International Conference on English Language Teaching: Advances in Social Science, Education and Humanities Research, vol. 145, pp. 12-15, 2017.

[12] L. R. Gay, G. E. Mills, and P. W. Airasian, Educational Research: Competencies for Analysis and Applications, $10^{\text {th }}$ Edition, New Jersey: Pearson Education, Inc, 2012.

[13] A. Sudijono, Pengantar Statistik Pendidikan, Jakarta: Rajali Pers, 2009.

[14] I. Azizah, "An Analysis of Students' Difficulties in Speaking English: A Case Study at Eleventh Grade Students of MA Al-Muslimun NW Tegal Academic Year 2015/2016," Universitas Mataram Repository, 16 August 2017. [Online]. http://eprints.unram.ac.id/152/ [Retrieved on October 3, 2019].

[15] H. D. Brown, Teaching by Principles: An Interactive Approach to Language Pedagogy, $2^{\text {nd }}$ Edition, New York: Pearson ESL, 2001. 